\title{
Blue light regulation of host pigment in reef-building corals
}

\author{
Cecilia D'Angelo ${ }^{1}$, Andrea Denzel ${ }^{1}$, Alexander Vogt ${ }^{1}{ }$, Mikhail V. Matz ${ }^{2}$, \\ Franz Oswald ${ }^{3}$, Anya Salih ${ }^{4}$, G. Ulrich Nienhaus ${ }^{5,6}$, Jörg Wiedenmann ${ }^{1,7, *}$ \\ ${ }^{1}$ Institute of General Zoology and Endocrinology, and ${ }^{5}$ Institute of Biophysics, \\ University of Ulm, Albert Einstein Allee 11, 89069 Ulm, Germany \\ ${ }^{2}$ Integrative Biology, University of Texas in Austin, 1 University Station C0930, Austin, Texas 78712, USA \\ ${ }^{3}$ Department of Internal Medicine I, Robert Koch Strasse 8, 89081 Ulm, Germany \\ ${ }^{4}$ Confocal Bio-Imaging Facility, University of Western Sydney, Hawkesbury Campus, Locked Bag 1797, Penrith South DC, \\ New South Wales 1797, Australia \\ ${ }^{6}$ Department of Physics, University of Illinois at Urbana-Champaign, 1110 West Green, Urbana, Illinois 61801, USA \\ ${ }^{7}$ Present address: National Oceanography Centre, University of Southampton, Waterfront Campus, European Way, \\ Southampton SO14 3ZH, UK
}

\begin{abstract}
Reef-building corals harbor an astounding diversity of colorful GFP (green fluorescent protein)-like proteins. These pigments can easily be detected and thus may serve as intrinsic optical markers of physiological condition, provided that the determinants that control their expression are well understood. Here we have analyzed the effect of light on the regulation of major classes of GFPlike pigments in corals of the taxa Acroporidae, Merulinidae and Pocilloporidae. Pigment levels in the tissues of all studied species were observed to be tightly controlled by light. Two groups could be distinguished by their distinctly different light-dependent regulation. The low-threshold group contains mainly cyan fluorescent proteins; they are expressed in considerable amounts at very low light intensities, and their tissue content increases with light to a maximum at a photon flux of $400 \mu \mathrm{mol} \mathrm{m}^{-2} \mathrm{~s}^{-1}$. The high-threshold group includes green and red fluorescent proteins as well as non-fluorescent chromoproteins. These pigments are essentially absent in corals grown under very low light, but their tissue content increases in proportion to photon flux densities $>400 \mu \mathrm{mol} \mathrm{m} \mathrm{m}^{-2} \mathrm{~s}^{-1}$. The enhancement of coral pigmentation is primarily dependent on the blue component of the spectrum and regulated at the transcriptional level. The specific regulation patterns suggest complex functions of GFP-like proteins related to the photobiology of reef corals. Moreover, the distinct response of coral coloration to light climate promises that the pigment complement can also be predicted in natural habitats. Our results stress the potential of GFP-like proteins as intrinsic markers of physiological processes, as well as overall health, in corals.
\end{abstract}

KEY WORDS: Fluorescent protein $\cdot$ Coral $\cdot$ Light-induced protein expression $\cdot$ Fluorescence $\cdot$ GFP · Green fluorescent protein $\cdot$ RFP $\cdot$ Red fluorescent protein · Light sensing $\cdot$ Coral health

\section{INTRODUCTION}

Coral reefs cover an area of 123 million $\mathrm{km}^{2}$ of tropical oceans and are among the most complex ecosystems in the world (Schuhmacher 1976). Hermatypic corals are primarily responsible for the formation of modern reefs. They owe their success in oligotrophic waters to the light-dependent symbiosis with unicellular dinoflagellate algae called zooxanthellae (Falkowski et al. 1984). Excessive light exposure, however, leads to photoinhibition of the symbionts and the generation of harmful reactive oxygen species, especially at elevated water temperatures (Gleason \& Wellington 1993, Brown 1997, Coles \& Brown 2003, Lesser 2006). Oxidative stress can trigger 
expulsion of zooxanthellae by the host, which results in bleaching of the coral tissue (Brown 1997, Coles \& Brown 2003, Smith et al. 2005, Lesser 2006). Mass mortality of bleached corals is frequently observed and contributes to the global degradation of coral reefs (Hughes et al. 2003, Donner et al. 2007).

Corals can acclimate to strong-light environments by controlling the type and/or number of harbored algal cells and their pigment content, and by adjusting the complement of UV-screening, mycosporin-like amino acids (MAAs) and antioxidant molecules (Falkowski \& Dubinsky 1981, Hoegh-Guldberg \& Smith 1989, Iglesias-Prieto \& Trench 1994, Shick et al. 1995, Rowan et al. 1997, Richier et al. 2005). A photoprotective function has also been suggested for the host pigments that are mainly responsible for the intense bluish, green, or reddish hues of many anthozoans living in symbiosis with zooxanthellae (Kawaguti 1944, Kawaguti 1969, Wiedenmann et al. 1999, Salih et al. 2000). However, green fluorescent protein (GFP)-like proteins are not restricted to symbiotic anthozoans but can also be found in azooxanthellate species from dim-light habitats (Wiedenmann et al. 2004, Schnitzler et al. 2008). These pigments are proteins related to the GFP from Aequorea victoria. Fluorescent proteins (FPs) emit light in the color range from cyan to red (Wiedenmann 1997, Matz et al. 1999, Wiedenmann et al. 2000, 2002, 2004, Dove et al. 2001, Shagin et al. 2004, Wiedenmann \& Nienhaus 2006, Oswald et al. 2007), whereas chromoproteins (CPs) display bright purple to blue colors but are non-fluorescent (Wiedenmann et al. 1999, 2000, Lukyanov et al. 2000, Dove et al. 2001, Shagin et al. 2004). In contrast to GFP, its anthozoan homologues usually form homotetramers (Nienhaus et al. 2003, $2005,2006 a, b)$. In recent years, proteins from the GFP family have become powerful tools in biomedical research. They have been employed as reporters of gene expression, variations of intracellular conditions (Griesbeck 2004), developmental processes, as protein labels in living cells (Wiedenmann \& Nienhaus 2006) and, most recently, in super-resolution imaging beyond the diffraction barrier (Shaner et al. 2007).

The high expression levels of GFP-like proteins in coral tissue (Oswald et al. 2007) and their advantageous photophysical properties make these pigments extremely promising as easily accessible indicators of the health of threatened coral reefs in a globally changing environment. To this end, a deep understanding of the regulation of the pigment levels is of utmost importance. As yet, only very few reports have focused on the influence of habitat conditions on the expression levels of GFP-like proteins. Montastrea annularis and $M$. faveolata from shallow water habitats did not contain more FPs than specimens from greater depths (Mazel et al. 2003). In Montastrea spp. and
Anemonia spp., expression levels of fluorescent and non-fluorescent GFP-like proteins were found to be genetically determined rather than modulated by the light environment (Kelmanson \& Matz 2003, Leutenegger et al. 2007b, Oswald et al. 2007). Down-regulation of GFP-like proteins was most recently reported in response to stressful environmental conditions including elevated water temperatures (Leutenegger et al. 2007b, Smith-Keune \& Dove 2007).

In contrast, we recently noticed that the green fluorescence of Acropora nobilis from the Heron Island reef flat was more intense in light-exposed parts of the branches, pointing to a light-dependent regulation of the pigment content. Likewise, a pink morph of Pocillopora damicornis showed an increase in pigmentation upon exposure to high light intensity (Takabayashi \& Hoegh-Guldberg 1995). The latter findings motivated us to systematically explore the expression of GFP-like proteins in reef corals upon exposure to light of varying intensity and color, using 5 different species of hermatypic corals (Acropora millepora, A. pulchra, Montipora digitata, Hydnophora grandis, and Seriatopora hystrix) from the taxa Acroporidae, Merulinidae and Pocilloporidae. Here we establish that tissue pigmentation is indeed modulated by light intensity in all these species, and that blue light triggers the regulation at the transcriptional level.

\section{MATERIALS AND METHODS}

Coral material. Coral specimens were acquired via the German aquarium trade and kept in artificial seawater at $25^{\circ} \mathrm{C}$ and a $12 \mathrm{~h}$ light: $12 \mathrm{~h}$ dark cycle in the sea water facility at the University of Ulm. Replicate colonies were incubated for at least 6 wk under moderate light intensity before being subjected to experimentation. All regeneration of replicates and experiments were performed within the same tank, ensuring that the specimens experienced identical water conditions.

Light treatments and spectroscopic analysis. The exposure of replicate coral colonies to different light conditions was performed as described by Leutenegger et al. (2007a). Briefly, colonies were split into 4 groups consisting of 6 colonies each and exposed to different intensities of white light at 80,100, 400 or $700 \mu \mathrm{mol}$ photons $\mathrm{m}^{-2} \mathrm{~s}^{-1}$, provided by a metal halide lamp (Aqua Light), for 6 wk. Afterwards, tissue fluorescence was excited by blue $(450 \mathrm{~nm})$ or green $(530 \mathrm{~nm})$ light; photographs were taken with a Camedia C-730 Ultra Zoom digital compact camera (Olympus) through a yellow long pass filter (Nightsea) or a $550 \mathrm{~nm}$ long pass glass filter (Schott). Fluorescence spectra of each specimen were measured using a Varian Cary Eclipse fluorescence spectrometer (Varian) equipped with a fiber optic probe. 
Illumination with different colors was achieved using lighting filters (Lee Filters) transmitting at $450 \mathrm{~nm}$ (band pass 'Zenith Blue', $80 \mathrm{~nm}$ full width at half maximum, FWHM), $512 \mathrm{~nm}$ (band pass, 'Dark Green', $80 \mathrm{~nm}$ FWHM) and >580 nm (long pass, Primary Red (see Supplementary Material, Appendix 1, available at: www.intres.com/articles/suppl/m364p97_app.pdf). The spectra were decomposed using MATLAB ${ }^{\circledR}$ (Mathworks). In all experiments using color filters, the specimens experienced a total photon flux of $200 \mu \mathrm{mol} \mathrm{m} \mathrm{m}^{-2} \mathrm{~s}^{-1}$ within the spectral range of $400-700 \mathrm{~nm}$ for $6 \mathrm{wk}$. The fluorescence of primary polyps of Acropora millepora was measured with a modified experimental setup as described in the Supplementary Material, Appendix 2.

Cleared coral tissue extracts were prepared from different individuals directly after spectroscopic characterization of the animal tissue as described by Leutenegger et al. (2007a) and Oswald et al. (2007). Total protein content was measured using the BCA method (Pierce). Proteins (10 $\mu \mathrm{g}$ total) were separated by sodium dodecyl sulphate polyacrylamide gel electrophoresis (SDS-PAGE) and transferred to polyvinyldiene difluoride (PVDF) membranes (Amersham). The differential regulation of GFP-like protein content was further analyzed by western blotting, using an antibody raised against coral FPs (Oswald et al. 2007).

Tissue extraction, protein content and western blot analyses. Cleared coral tissue extracts were prepared as described by Leutenegger et al. (2007a) and Oswald et al. (2007). Total protein content was measured using the BCA method (Pierce). Proteins (10 $\mu \mathrm{g}$ total) were separated by sodium dodecyl sulphate polyacrylamide gel electrophoresis (SDS-PAGE) and transferred to polyvinyldiene difluoride (PVDF) membranes (Amersham). The differential regulation of GFP-like protein content was further analyzed by western blotting, using an antibody raised against coral FPs (Oswald et al. 2007). Protein extracts were prepared from different individuals directly after spectroscopic characterization of the animal tissue.

RNA preparation and RT-PCR. RNA was prepared from tissues of Acropora millepora and A. pulchra after exposure to blue, green or red light for $6 \mathrm{wk}$. Using primers specific for amilFP484, amilF597, apulFP483 and apulCP584, fragments with the correct length of 700 base pairs were amplified.

For transcript analyses, approximately $100 \mathrm{mg}$ of coral tissue was quickly frozen in liquid $\mathrm{N}_{2}$. Total RNA was extracted using RNAqueous ${ }^{\circledR}$ (Ambion). The RNA concentration of each sample was determined spectroscopically; the RNA quality was analyzed on an agarose gel. cDNA was produced from $1 \mu \mathrm{g}$ of RNA using 100 units of Moloney murine leukemia virus (MMLV) reverse transcriptase (Promega) in the presence of $8 \mathrm{mM}$ dNTPs, $16 \mathrm{U}$ RNasin (Promega) and $500 \mathrm{ng}$ of
oligo-dT primer (Promega). Fragments encoding GFPlike proteins and the housekeeping genes GAPDH (glyceraldehyde-3-phosphate dehydrogenase) and AmES (Acropora millepora expressed sequence, GenBank accession number DY587236, Kortschak et al. 2003) were amplified from 100 ng of cDNA (primer sequences are given in Appendix 3). The number of PCR cycles was individually optimized to ensure that the samples were analyzed during exponential amplification. Equal amounts $(10 \mu \mathrm{l})$ of each PCR reaction were visualized on ethidium bromide-stained agarose gels and photographed with the Bio-Rad Fluor-S Multilmager (Bio-Rad). The intensity of every transcript band was quantified using Adobe Photoshop 5.0 Software (Adobe Systems) and normalized to the 2 analyzed housekeeping genes. The amplified FP cDNAs (amilFP484/497/512//597, apulFP483 and apulCP584) were cloned and the encoded proteins were characterized as described by Wiedenmann et al. (2005).

To study the response of corals to a changed light stimulus, specimens were incubated for $6 \mathrm{wk}$ under red light and subsequently transferred to blue light, after which samples were taken over a period of $8 \mathrm{~h}$. Following this, 2 colonies were maintained in red light and analyzed as a negative control and 2 were maintained in blue light for another $4 \mathrm{wk}$ and their transcript levels analyzed as a positive control.

Statistical analysis. The software ANALYSE IT for Microsoft Excel, Version 1.73 (Microsoft) was used for statistical analyses. Using Student's $t$-test (2 independent groups), 2-tailed p-values $<0.05$ were considered statistically significant. Highly significant differences were assumed for $\mathrm{p}$-values $<0.01$. The probability values and sample numbers used for statistical analysis are listed in Appendix 4.

\section{RESULTS AND DISCUSSION}

\section{Identification of GFP-like proteins in coral tissue}

The 5 coral species studied contained a variety of pigments ranging from cyan to red, which showed elution profiles in size exclusion chromatography typical of GFP-like proteins (Wiedenmann et al. 2005). The protomers of the tetrameric assemblies have a molecular mass of $\sim 26 \mathrm{kDa}$, as determined by SDS-PAGE and immunoblot analysis using an antiserum raised against coral fluorescent proteins (Oswald et al. 2007). Further evidence of the GFP-like nature of these pigments was provided by cloning and sequencing of 2 representatives of Acropora pulchra and 6 of A. millepora (Table 1). The proteins amilFP484, amilFP512 and amilFP597 displayed $>97 \%$ amino acids identical to those of other, previously sequenced GFP-like proteins 
Table 1. Hydnophora grandis, Seriatopora hystrix, Montipora digitata, Acropora pulchra, and A. millepora. Spectral properties of green fluorescent protein (GFP)-like protein. $\lambda_{\mathrm{Abs} / \mathrm{Ex}} / \lambda_{\mathrm{Em}}$ : position of the absorption (Abs) or excitation (Ex) maximum given as wavelength $\lambda(\mathrm{nm}) /$ Position of the emission (Em) maximum given as wavelength (nm); protein name: proteins were named according to Cox et al. (2007); Chromophore structure: basic structural features were deduced from the absorption of the denatured protein in $0.1 \mathrm{~N}$ $\mathrm{NaOH}$ (Gross et al. 2000, Oswald et al. 2007); CFP: cyan fluorescent protein; CP: chromoprotein; OFP: orange fluorescent protein; RFP: red fluorescent protein

\begin{tabular}{|c|c|c|c|c|c|}
\hline & $\begin{array}{l}\text { Pigment } \\
\text { class }\end{array}$ & $\begin{array}{l}\lambda_{\mathrm{Abs} / \mathrm{Ex}} / \lambda_{\mathrm{Em}} \\
(\mathrm{nm})\end{array}$ & $\begin{array}{l}\text { Protein } \\
\text { name }\end{array}$ & $\begin{array}{l}\text { Chromophore } \\
\text { structure }\end{array}$ & $\begin{array}{c}\text { GenBank } \\
\text { accession no. }\end{array}$ \\
\hline Hydnophora grandis & CFP & $443 / 492^{\mathrm{a}}$ & hgraFP492 & GFP & - \\
\hline Seriatopora hystrix & $\mathrm{CP}$ & $562^{\mathrm{a}}$ & shysCP562 & dsRed & - \\
\hline Montipora digitata & $\begin{array}{l}\text { CFP } \\
\text { GFP } \\
\text { OFP }\end{array}$ & $\begin{array}{l}470 / 486^{\mathrm{a}} \\
508 / 514^{\mathrm{a}} \\
556 / 572^{\mathrm{a}}\end{array}$ & $\begin{array}{l}\text { mdigFP486 } \\
\text { mdigFP514 } \\
\text { mdigFP572 }\end{array}$ & $\begin{array}{c}\text { GFP } \\
\text { GFP } \\
\text { dsRed }\end{array}$ & $\begin{array}{l}- \\
- \\
-\end{array}$ \\
\hline Acropora pulchra & $\begin{array}{l}\text { CFP } \\
\text { CP }\end{array}$ & $\begin{array}{c}420 / 483^{\mathrm{b}} \\
584^{\mathrm{b}}\end{array}$ & $\begin{array}{l}\text { apulFP483 } \\
\text { apulCP584 }\end{array}$ & $\begin{array}{l}\text { GFP } \\
\text { dsRed }\end{array}$ & $\begin{array}{l}\text { apulFP483 EU709806 } \\
\text { apulCP584 EU709807 }\end{array}$ \\
\hline Acropora millepora & $\begin{array}{l}\text { CFP } \\
\text { GFP } \\
\text { GFP } \\
\text { RFP }\end{array}$ & $\begin{array}{l}420 / 484^{\mathrm{b}} \\
477 / 497^{\mathrm{b}} \\
500 / 512^{\mathrm{b}} \\
558 / 597^{\mathrm{b}}\end{array}$ & $\begin{array}{l}\text { amilFP484 } \\
\text { amilFP497 } \\
\text { amilFP512 } \\
\text { amilFP597 }\end{array}$ & $\begin{array}{l}\text { GFP } \\
\text { GFP } \\
\text { GFP } \\
\text { dsRed }\end{array}$ & $\begin{array}{l}\text { amilFP484 EU709808 } \\
\text { amilFP497 EU709809 } \\
\text { amilFP512 EU709810 } \\
\text { amilFP597 EU709811 }\end{array}$ \\
\hline
\end{tabular}

from A. millepora (Cox et al. 2007) (GenBank accession numbers DQ206400, AY646073 and AY646070). The identified pigments represent major color classes of GFP-like proteins, namely cyan, green, orange and red fluorescent proteins and also non-fluorescent pink or purple-blue chromoproteins (Table 1).

\section{Effect of light intensity on GFP-like protein expression}

Coral pigmentation was analyzed after subjecting colonies of each species for 6 wk to 4 different light intensities (photon flux densities), which we classify as very low $\left(80 \mu \mathrm{mol} \mathrm{m}^{-2} \mathrm{~s}^{-1}\right)$, low $\left(100 \mu \mathrm{mol} \mathrm{m} \mathrm{m}^{-2} \mathrm{~s}^{-1}\right)$, moderate $\left(400 \mu \mathrm{mol} \mathrm{m}{ }^{-2} \mathrm{~s}^{-1}\right)$ and high $\left(700 \mu \mathrm{mol} \mathrm{m} \mathrm{m}^{-2} \mathrm{~s}^{-1}\right)$. As indicated by the gain of wet weight of coral colonies, growth rates under low light reached 20 to $40 \%$ of the rates determined for specimens under moderate light (data not shown). Consequently, colonies from low light treatments were smaller than their counterparts grown under moderate light (Fig. 1A-E).
Colonies illuminated with low-intensity light appeared brownish, whereas those growing under moderate light displayed distinctive hues ranging from blue over green to reddish. The increase in pigmentation of moderate-light-treated specimens was striking when the tissue fluorescence was excited with blue or green light (Fig. 1A-E).

The amount of pigments was quantified by measuring the emission of FPs directly on the corals or by collecting absorption spectra of size-fractionated tissue extracts. In 4 cases, varying light treatments were observed to modulate the spectral amplitude without changing the overall shape (Fig. 1F-I). An exception was the change in the ratio of the 2 emission bands at $\sim 490$ and $\sim 510 \mathrm{~nm}$ of Acropora millepora upon light intensity variation (Fig. 1J). These overall emission spectra taken from tissues can be decomposed using the spectra of the 3 recombinant proteins amilFP484, amilFP497 and amilFP512 (Table1) cloned from one of the individuals used in the experiments.

Fig. 1. Hydnophora grandis, Seriatopora hystrix, Montipora digitata, Acropora pulchra, and A. millepora. Effect of light intensity on the content of green fluorescent protein (GFP)-like proteins: (A-E) Images of corals kept for 6 wk in photon flux densities of $100 \mu \mathrm{mol}$ $\mathrm{m}^{-2} \mathrm{~s}^{-1}$ (low light, L) or $400 \mu \mathrm{mol} \mathrm{m} \mathrm{s}^{-2} \mathrm{~s}^{-1}$ (moderate light, M). All species were photographed under white light illumination (upper panels). Lower panels in $(A, C, D)$ and middle panel in (E) depict tissue fluorescence imaged under blue light excitation. Lower panel in (E) shows red tissue fluorescence excited by green light. (F-J) Fluorescence and/or absorption (Abs) spectra after light exposure (mean + SD from 12 to 33 measurements). Maximum peak in every graph was set to 100 while the others were normalized accordingly. Fluorescence was measured directly on the replicate colonies, whereas the chromoprotein absorption spectra of $S$. hystrix (G) and A. pulchra (I) were determined from the peak fraction of size-fractionated tissue extracts and normalized to the total protein content of the samples. The photon fluxes of the treatments $\left(\mu \mathrm{mol} \mathrm{m}{ }^{-2} \mathrm{~s}^{-1}\right)$ are given in the keys. (K-O) Tissue fluorescence and/or absorption at the peak wavelength (nm) specified in the key of each graph. Cyan and green fluorescence intensities in (O) represent results from the spectral decomposition. ${ }^{* *}$ Highly significant difference $(\mathrm{p}<0.01$, independent $t$-test) compared to the closest lower photon flux 

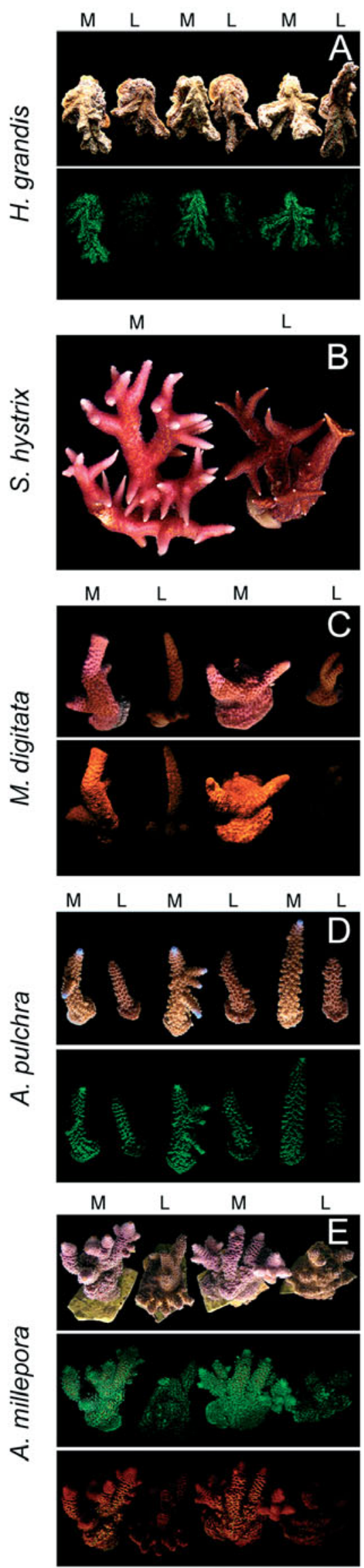
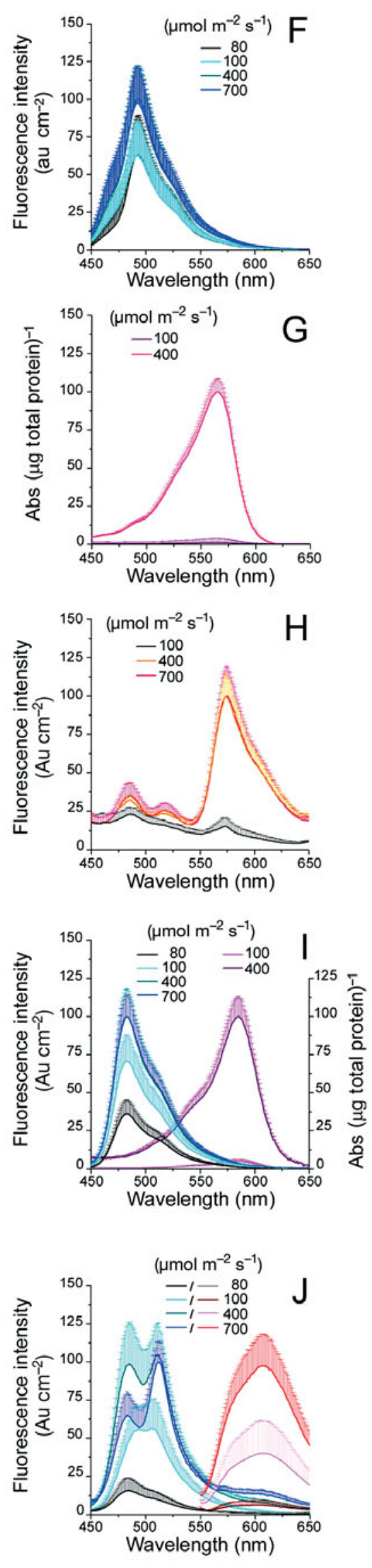
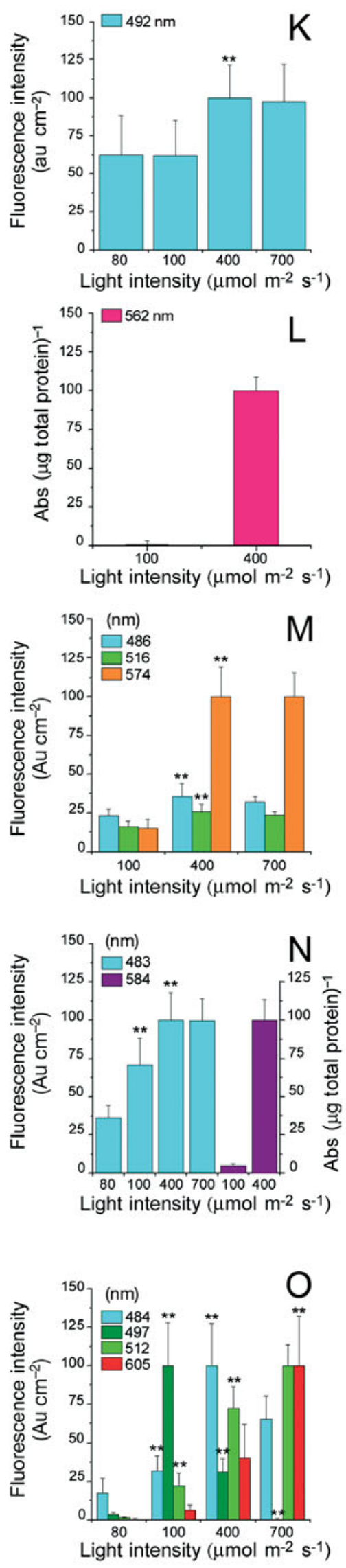
Based on the response to light intensity, 2 different groups of proteins could be distinguished: a lowthreshold group that includes all cyan fluorescent proteins (CFPs) in the present study, mdigFP514, mdigFP572 and amilFP497, and a high-threshold group consisting of amilFP512, amilFP597, and all CPs from Acropora pulchra and Seriatopora hystrix. Proteins of the high-threshold group were essentially absent when the light intensity fell below $100 \mu \mathrm{mol}$ photons $\mathrm{m}^{-2} \mathrm{~s}^{-1}$, and they accumulated nearly in proportion to light intensity up to $700 \mu \mathrm{mol}$ photons $\mathrm{m}^{-2} \mathrm{~s}^{-1}$. In contrast, representatives of the low-threshold group were expressed in considerable amounts at low light intensity, reaching their highest expression levels at a photon flux of $\leq 400 \mu \mathrm{mol}$ photons $\mathrm{m}^{-2} \mathrm{~s}^{-1}$ and either saturating or even decreasing at higher light intensity. These results demonstrate unambiguously that the expression of GFP-like proteins in these corals is tightly controlled by light. Consequently, a variety of genes encoding GFPlike proteins regulated by environmental conditions can be clearly distinguished from another set constitutively expressed in the coral tissue (Kelmanson \& Matz 2003, Leutenegger et al. 2007b, Oswald et al. 2007).

\section{Effect of light color on GFP-like protein expression}

Exposure of replicate colonies of each species to red, green or blue light at a photon flux of $200 \mu \mathrm{mol} \mathrm{m} \mathrm{m}^{-2} \mathrm{~s}^{-1}$ showed that corals incubated with blue light had the highest amounts of GFP-like proteins. Pigments of the low-threshold group were consistently found in corals growing in red light and reached $\geq 50 \%$ of the expression levels achieved with green light irradiation (Appendix 5). In contrast, representatives of the highthreshold group were essentially undetectable in corals grown under red light, and green-light-exposed specimens did not reach $50 \%$ of the levels observed under blue light.

Western blot analyses to further characterize the differential regulation of GFP-like protein content showed that, in all examined coral species, the antibody revealed the $\sim 26 \mathrm{kDa}$-band typical of GFP-like proteins (Fig. 2A-F). The observed band intensities further confirmed that the concentrations of FPs or CPs were always highest for blue-light-treated specimens.

The differences in pigment content between corals incubated under low and moderate light are similar to those between green and blue-light-exposed specimens (Appendix 5). The metal halide lamps used to illuminate the corals emit $\sim 50 \%$ of the photons in the blue spectral region. Therefore, corals subjected to low or moderate light treatment experienced a photon flux of $\sim 50$ or $\sim 200 \mu \mathrm{mol} \mathrm{m} \mathrm{m}^{-2} \mathrm{~s}^{-1}$ of blue light, respectively. The green filter utilized in our experiments still trans- mits $\sim 25 \%$ of the photons, corresponding to a photon flux of $\sim 50 \mu \mathrm{mol} \mathrm{m} \mathrm{m}^{-2} \mathrm{~s}^{-1}$, in the blue region of the spectrum (Appendix 1). Therefore, the light-driven accumulation of GFP-like proteins observed upon green light exposure is likely due to residual blue light passing the green filter. The expression of GFP-like proteins in members of the low-threshold group under red light suggests that a constitutive basal expression exists.

\section{Regulation of GFP-like protein expression in corals}

Semiquantitative RT-PCR was performed to determine whether the pigment content was regulated at the transcriptional level. As expected from the similarity between cyan and green FPs from Acropora millepora that were sequenced earlier (Cox et al. 2007), PCR with amilFP484 primers also led to amplification of cDNAs encoding amilFP497 and amilFP512 (Fig. 3A,B). Low transcription levels of the amilFP484/497/512 group and amilFP597 were detected in A. millepora exposed to red light. A major increase in the amount of FP transcripts occurred with green light, and a further increment with blue light exposure, indicating a regulation of the tissue pigment content at the transcriptional level. The transcript of the low-threshold protein apulFP483 was already present in red-light-illuminated $A$. pulchra; its amount increased to a maximum level for green-light-exposed specimens. This result agrees well with the small changes in tissue fluorescence due to proteins of the low-threshold group for illumination with blue and green light. In contrast, the transcript level of the high-threshold protein apulCP584 was significantly higher upon exposure to blue light.

RT-PCR analysis was performed to determine the time the corals require to increase transcript levels in response to a changed light stimulus. FP transcripts accumulated at very low levels at time point 0 (i.e. immediately before exposure to blue light, Fig. 3C,D) and in specimens treated for another $8 \mathrm{~h}$ with red light. In contrast, transcript levels were significantly increased after $8 \mathrm{~h}$ of exposure to blue light. However, after $8 \mathrm{~h}$ of stimulation, the maximal transcript level was not yet reached, as shown by comparison with the levels in the positive control group after $4 \mathrm{wk}$ of blue-light exposure. This rather slow increase suggests that the accumulation of pigments is a long-term adaptive process.

\section{Fluorescence in primary polyps of Acropora millepora}

Further investigations were conducted to test whether the presence of endosymbiotic algae is mandatory for the regulation of GFP-like proteins. Examination of azooxanthellate primary polyps (exposed to red or blue light 

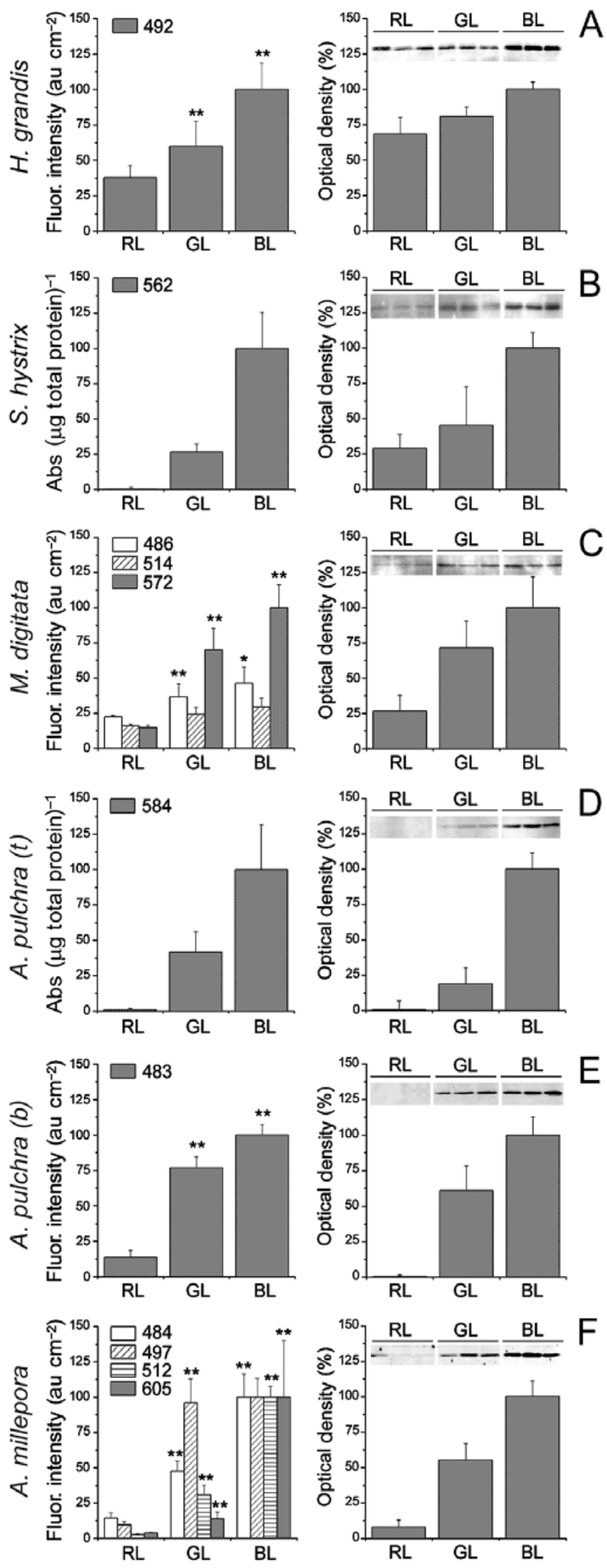

Fig. 2. Hydnophora grandis, Seriatopora hystrix, Montipora digitata, Acropora pulchra, and A. millepora. Effect of light energy (color) on the accumulation of green fluorescent protein (GFP)like proteins. Replicate colonies were exposed to red (RL), green (GL) or blue light (BL) (photon flux of $200 \mu \mathrm{mol} \mathrm{m} \mathrm{m}^{-2} \mathrm{~s}^{-1}$ ). Left graph of each panel gives the fluorescence emission or absorption (Abs) of fluorescent proteins (FPs) and chromatoproteins (CPs), respectively (corresponding wavelengths in $\mathrm{nm}$ indicated in the keys). Bars represent the mean (+SD) of 12 to 33 measurements. Significant $\left({ }^{*} p<0.05\right)$ or highly significant $\left({ }^{* *} p<0.01\right)$ differences, as calculated by independent $t$-test between GL and RL exposed specimens (asterisk on the GL bars), or between BL and GL exposed specimens (asterisks on the BL bars). Right graph of each panel displays the results of western blot analyses of tissue extracts prepared at the end of the experiment. Three independent measurements of the optical density of the bands specific for GFP-like proteins (insets) were made. Data are means (+SD), with values from BL exposure set to 100 and all other data normalized accordingly

immediately after metamorphosis) by fluorescence microscopy after $5 \mathrm{~d}$ of illumination revealed a significant increase of tentacle fluorescence in the green spectral region (Fig. 4). This suggests that photoreceptors of the host are involved in the regulation of pigment levels. Perception of blue-green light by the ectodermal, zooxanthellae-free cells of Montastrea cavernosa and Eusmilia fastigiata was demonstrated earlier (Gorbunov \& Falkowski 2002), and only very recently, cryptochromes were identified in Acropora millepora, providing putative blue-light photoreceptors (Levy et al. 2007).

\section{Implications for biological function}

Among the known FPs and CPs, only the absorption properties of CFPs spectrally match the major absorption band of chlorophyll $a$ and $c$ at $\sim 430 \mathrm{~nm}$, making them suitable for effective shielding of the photosynthetic system of the zooxanthellae. Our results have shown that the amounts of these proteins in coral tissue increased at light intensities $>80 \mu \mathrm{mol} \mathrm{m}^{-2} \mathrm{~s}^{-1}$ and saturated at $\sim 400 \mu \mathrm{mol} \mathrm{m}{ }^{-2} \mathrm{~s}^{-1}$. This response is in striking agreement with photosynthesis-irradiance curves of zooxanthellae from different coral species that show a similar increase and saturation at $400 \mu \mathrm{mol} \mathrm{m} \mathrm{m}^{-2} \mathrm{~s}^{-1}$ (Falkowski et al. 1990, Smith et al. 2005). However, the detrimental effects of excessive light levels become apparent once photosynthesis is saturated and the generation of reactive oxygen species (ROS) increases (Smith et al. 2005, Lesser 2006). If CFPs and other members of the low-threshold group were exclusively involved in a photoprotective function, an upregulation of these proteins should be expected, especially at photon fluxes higher than $400 \mu \mathrm{mol} \mathrm{m} \mathrm{m}^{-2} \mathrm{~s}^{-1}$. Our data do not favor such a scenario, so these pigments might also play other roles in the interaction of the coral host and its algal symbionts. Possible functions might include sensing of 

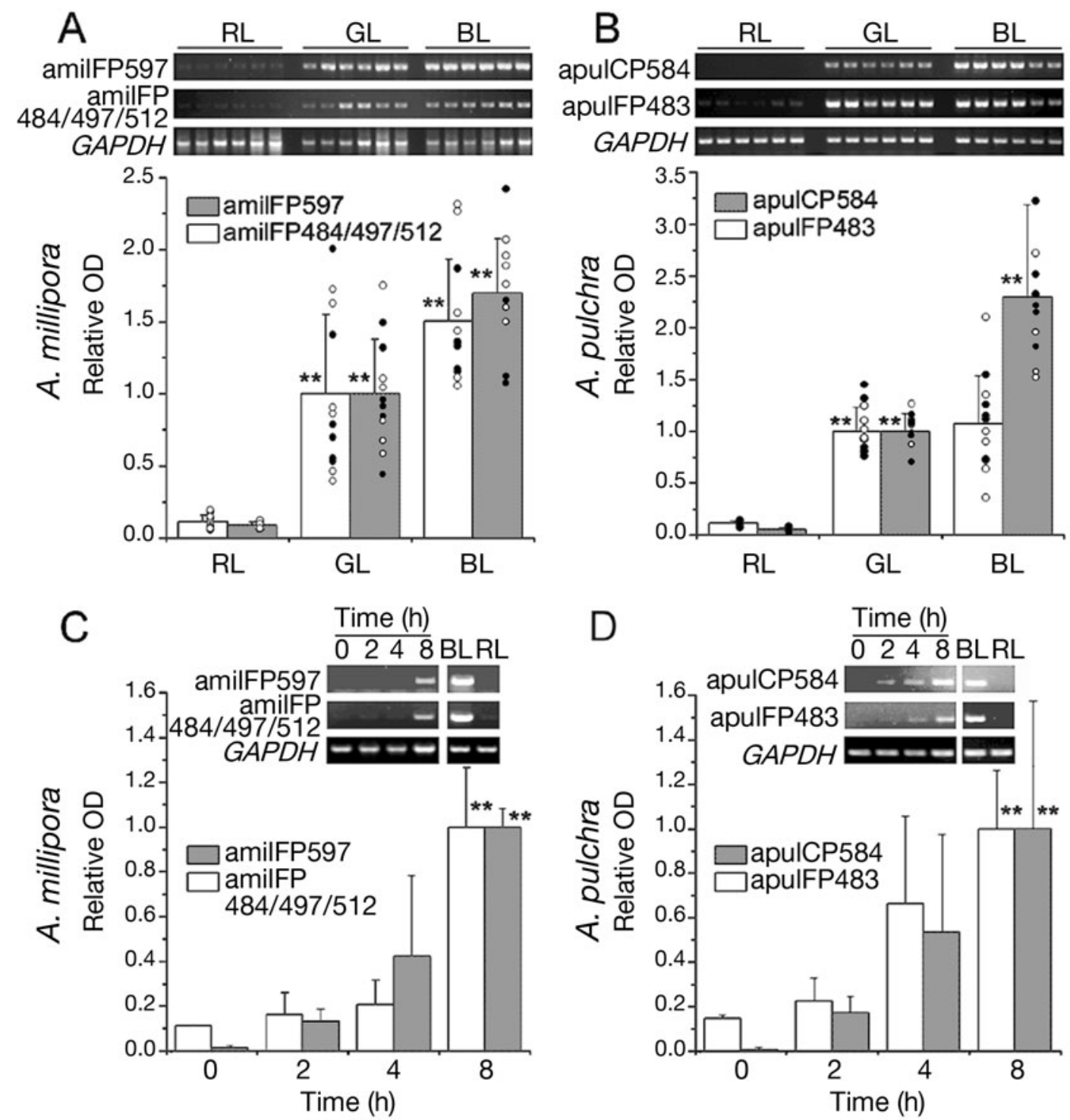

Fig. 3. Acropora pulchra and Acropora millepora. Semi-quantitative RT-PCR analysis of green fluorescent protein (GFP)-like protein transcripts: (A,B) Semi-quantitative analysis of transcript levels after treatment with red (RL), green (GL) or blue light (BL) (photon flux of $200 \mu \mathrm{mol} \mathrm{m} \mathrm{s}^{-2} \mathrm{~s}^{-1}$ ). Representative ethidium bromide-stained gels in the upper part of the panels show the bands corresponding to amplified transcripts of GFP-like proteins and the housekeeping gene GAPDH. As gel analysis of transcript levels of the housekeeping gene AmES yielded results comparable to GAPDH, the respective panels were omitted for space reasons. Data are means (+SD) of the intensities of replicate bands from 6 independent measurements, normalized to the corresponding bands of the housekeeping genes GAPDH and AmES. Open and filled circles depict values obtained by normalization to GAPDH and to $A m E S$, respectively. (C,D) A. millepora and A. pulchra specimens transferred from RL to BL (time point $0 \mathrm{~h}$ ). Samples were taken after 2, 4 and $8 \mathrm{~h}$ of BL exposure and used for RT-PCR analysis. Control specimens incubated for $8 \mathrm{~h}$ under RL and $4 \mathrm{wk}$ under BL were processed in parallel. OD: optical density, ${ }^{* *}$ highly significant differences $(\mathrm{p}<0.01$, independent $t$-test)

photosynthetic activity of zooxanthellae, support of algal productivity by the addition or removal of ratelimiting substances, or accumulation of the pigments for amino acid or nitrogen storage purposes. A close spatial association with zooxanthellae required for such functions was previously observed for certain coral FPs (Mazel et al. 2003, Oswald et al. 2007).

The light-induced upregulation of GFP-like proteins from the high-threshold group resembles the increas- ing accumulation of well known photoprotectants such as MAAs, $\beta$-carotene, xanthophylls or melanins (Shick et al. 1995, Bandaranayake 2006). However, none of the members of the high-threshold group absorbs light at wavelengths that would provide an efficient shielding of the photosynthetic apparatus of the zooxanthellae. The screening effect could be enhanced if these proteins were to act as acceptors in fluorescence resonance energy transfer (FRET) (Gilmore et al. 2003, Cox 

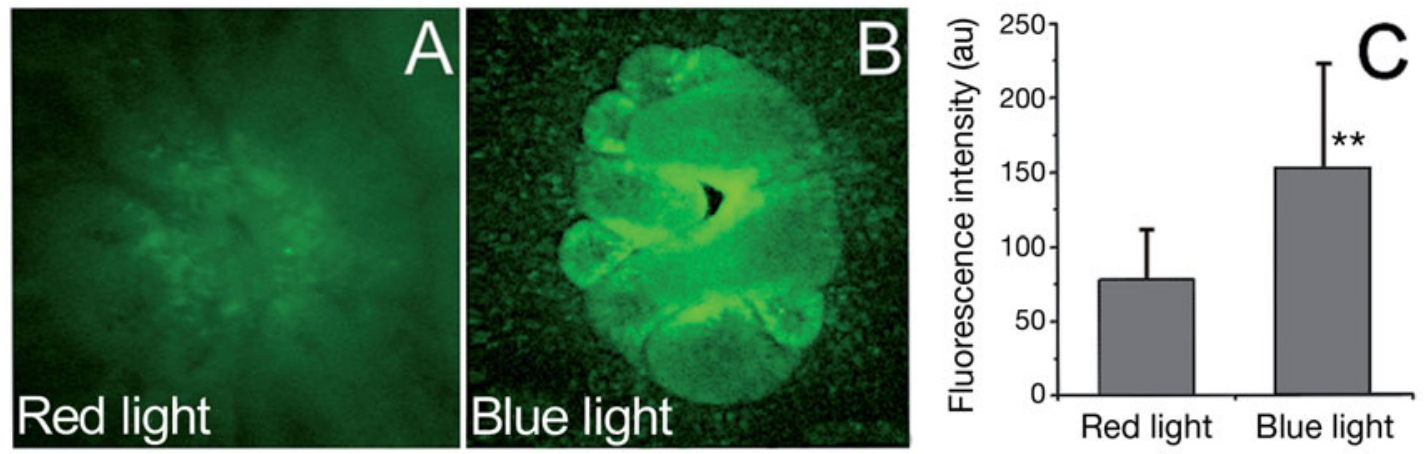

Fig. 4. Acropora millepora. Upregulation of green fluorescent protein (GFP)-like protein expression in primary polyps. Fluorescence photomicrographs of tentacles treated with (A) red and (B) blue light. (C) Green fluorescence (mean + SD) of tentacles from red and blue light-treated polyps from 28 independent measurements. ${ }^{* *}$ Highly significant differences $(\mathrm{p}<0.01$, independent $t$-test)

et al. 2007). Alternatively, protection from harmful light effects could also involve an as yet undiscovered function, for instance ROS scavenging (Bou-Abdallah et al. 2006) or antimicrobial defense of corals becoming vulnerable under light stress. Interestingly, in the case of Acropora pulchra, the strong accumulation of apulCP584 was limited to the tips of the branches. The apical polyps are essentially free of zooxanthellae, but are the areas with the highest growth rates (Fang et al. 1989). The constrained localization of some FPs in zooxanthellae-free parts of certain corals (e.g. skeletal ridges) has been noticed earlier (Mazel et al. 2003). Therefore, GFP-like proteins, particularly representatives of the high-threshold group, could play a role in metabolic pathways related to coral growth.

\section{Coral color as an indicator of environmental conditions}

In this work, we have established the tight regulation of GFP-like proteins in corals from different taxonomic groups in response to the intensity and spectral composition of the irradiating light. Consequently, the pigment complement of coral species that express representatives of both high- and low-threshold groups, might serve as a predictable 'ratiometric' indicator of light conditions in the habitat. In conclusion, coral pigmentation appears promising as a sensitive indicator of environmental conditions. Future work will further refine our knowledge about the influence of diverse environmental factors on the expression levels of GFPlike proteins in reef-building corals.

Acknowledgements. The authors thank A. Kobitski, Institute of Biophysics, University of Ulm, for decomposition of spectra, and V. Beltran Ramirez, A. Reyes and D. J. Miller, James Cook University, Townsville, Australia, for expert advice on handling coral larvae. This work was supported by the Deutsche Forschungsgemeinschaft (SFB497/B9 to F.O., SFB497/D2 and SFB569/A4 to G.U.N., and Wi1990/2-1 to J.W.), Fluorescence
Applications in Biotechnology and Life Sciences, Australia (to A.S. et al.), National Institutes of Health (GM66243 to M.M.) and the Deutscher Akademischer Austausch Dienst (to J.W.).

\section{LITERATURE CITED}

Bandaranayake WM (2006) The nature and role of pigments of marine invertebrates. Nat Prod Rep 23:223-255

Bou-Abdallah F, Chasteen ND, Lesser MP (2006) Quenching of superoxide radicals by green fluorescent protein. Biochim Biophys Acta 1760:1690-1695

Brown BE (1997) Coral bleaching: causes and consequences. Coral Reefs 16(Suppl):S129-S138

Coles SL, Brown BE (2003) Coral bleaching-capacity for acclimatization and adaptation. Adv Mar Biol 46:183-223

Cox G, Matz M, Salih A (2007) Fluorescence lifetime imaging of coral fluorescent proteins. Microsc Res Tech 70:243-251

> Donner SD, Knutson TR, Oppenheimer M (2007) Modelbased assessment of the role of human-induced climate change in the 2005 Caribbean coral bleaching event. Proc Natl Acad Sci USA 104:5483-5488

Dove SG, Hoegh-Guldberg O, Ranganathan S (2001) Major colour patterns of reef-building corals are due to a family of GFP-like proteins. Coral Reefs 19:197-204

Falkowski PG, Dubinsky Z (1981) Light-shade adaptation of Stylophora pistillata, a hermatypic coral from the Gulf of Eilat. Nature 289:172-174

Falkowski PG, Dubinsky Z, Muscatine L, Porter JW (1984) Light and the bioenergetics of a symbiotic coral. Bioscience 34:705-709

Falkowski PG, Jokiel PL, Kinzie RA III (1990) Irradiance and corals. In: Dubinsky Z (ed) Ecosystems of the world, Vol 25. Coral reefs. Elsevier, p 89-107

Fang LS, Chen YWJ, Chen CS (1989) Why does the white tip of stony coral grow so fast without zooxanthellae? Mar Biol 103:359-363

Gilmore AM, Larkum AWD, Salih A, Itoh S and others (2003) Simultaneous time resolution of the emission spectra of fluorescent proteins and zooxanthellar chlorophyll in reefbuilding coral. Photochem Photobiol 77:515-523

Gleason DF, Wellington GM (1993) Ultraviolet radiation and coral bleaching. Nature 365:836-838

Gorbunov MY, Falkowski PG (2002) Photoreceptors in the cnidarian hosts allow symbiotic corals to sense blue moonlight. Limnol Oceanogr 47:309-315

Griesbeck O (2004) Fluorescent proteins as sensors for cellular functions. Curr Opin Neurobiol 14:636-641 
Gross LA, Baird GS, Hoffman RC, Baldridge KK, Tsien RY (2000) The structure of the chromophore within DsRed, a red fluorescent protein from coral. Proc Natl Acad Sci USA 97:11990-11995

- Hoegh-Guldberg O, Smith GJ (1989) The effect of sudden changes in temperature, light and salinity on the population density and export of zooxanthellae from the reef corals Stylophora pistillata Esper and Seriatopora hystrix Dana. J Exp Mar Biol Ecol 129:279-303

Hughes TP, Baird AH, Bellwood DR, Card M and others (2003) Climate change, human impacts, and the resilience of coral reefs. Science 301:929-933

Iglesias-Prieto R, Trench RK (1994) Acclimation and adaptation to irradiance in symbiotic dinoflagellates. I. Responses of the photosynthetic unit to changes in photon flux density. Mar Ecol Prog Ser 113:163-175

Kawaguti S (1944) On the physiology of reef corals. VI Study on the pigments. Palao Trop Biol Stn Stud 2:617-674

Kawaguti S (1969) Effect of the green fluorescent pigment on the productivity of the reef corals. Micronesica 5:313

Kelmanson IV, Matz MV (2003) Molecular basis and evolutionary origins of color diversity in great star coral Montastraea cavernosa (Scleractinia: Faviida). Mol Biol Evol 20: 1125-1133

Kortschak RD, Samuel G, Saint R, Miller DJ (2003) EST analysis of the cnidarian Acropora millepora reveals extensive gene loss and rapid sequence divergence in the model invertebrates. Curr Biol 13:2190-2195

Lesser MP (2006) Oxidative stress in marine environments: biochemistry and physiological ecology. Annu Rev Physiol 68:253-278

Leutenegger A, D'Angelo C, Matz MV, Denzel A and others (2007a) It's cheap to be colorful. Anthozoans show a slow turnover of GFP-like proteins. FEBS J 274:2496-2505

> Leutenegger A, Kredel S, Gundel S, D'Angelo C, Salih A, Wiedenmann J (2007b) Analysis of fluorescent and nonfluorescent sea anemones from the Mediterranean Sea during a bleaching event. J Exp Mar Biol Ecol 353:221-234

> Levy O, Appelbaum L, Leggat W, Gothlif Y, Hayward DC, Miller DJ, Hoegh-Guldberg O (2007) Light-responsive cryptochromes from a simple multicellular animal, the coral Acropora millepora. Science 318:467-470

Lukyanov KA, Fradkov AF, Gurskaya NG, Matz MV and others (2000) Natural animal coloration can be determined by a nonfluorescent green fluorescent protein homolog. J Biol Chem 275:25879-25882

Matz MV, Fradkov AF, Labas YA, Savitsky AP, Zaraisky AG, Markelov ML, Lukyanov SA (1999) Fluorescent proteins from nonbioluminescent Anthozoa species. Nat Biotechnol 17:969-973

Mazel CH, Lesser MP, Gorbunov MY, Barry TM, Farrell JH, Wyman KD, Falkowski PG (2003) Green-fluorescent proteins in Caribbean corals. Limnol Oceanogr 48:402-411

Nienhaus K, Vallone B, Renzi F, Wiedenmann J, Nienhaus GU (2003) Crystallization and preliminary X-ray diffraction analysis of the red fluorescent protein eqFP611. Acta Cryst D59:1253-1255

Nienhaus K, Nienhaus GU, Wiedenmann J, Nar H (2005) Structural basis for photo-induced protein cleavage and green-to-red conversion of fluorescent protein EosFP. Proc Natl Acad Sci USA 102:9156-9159

Nienhaus $\mathrm{K}$, Renzi F, Vallone B, Wiedenmann J, Nienhaus GU (2006a) Chromophore-protein interactions in the anthozoan green fluorescent protein asFP499. Biophys J 91:4210-4220

Nienhaus K, Renzi F, Vallone B, Wiedenmann J, Nienhaus GU (2006b) Exploring chromophore-protein interactions in fluorescent protein cmFP512 from Cerianthus membranaceus: X-ray structure analysis and optical spectro- scopy. Biochemistry 45:12942-12953

Oswald F, Schmitt F, Leutenegger A, Ivanchenko S and others (2007) Contributions of host and symbiont pigments to the coloration of reef corals. FEBS J 274:1102-1109

Richier S, Furla P, Plantivaux A, Merle PL, Allemand D (2005) Symbiosis-induced adaptation to oxidative stress. J Exp Biol 208:277-285

Rowan R, Knowlton N, Baker A, Jara J (1997) Landscape ecology of algal symbionts creates variation in episodes of coral bleaching. Nature 388:265-269

Salih A, Larkum A, Cox G, Kuhl M, Hoegh-Guldberg O (2000) Fluorescent pigments in corals are photoprotective. Nature 408:850-853

Schnitzler CE, Keenan RJ, McCord R, Matysik A, Christianson LM, Haddock SH (2008) Spectral diversity of fluorescent proteins from the anthozoan Corynactis californica. Mar Biotechnol

Schuhmacher H (1976) Korallenriffe: ihre Verbreitung, Tierwelt und Oekologie. BLV, Munich

> Shagin DA, Barsova EV, Yanushevich YG, Fradkov AF and others (2004) GFP-like proteins as ubiquitous metazoan superfamily: evolution of functional features and structural complexity. Mol Biol Evol 21:841-850

> Shaner NC, Patterson GH, Davidson MW (2007) Advances in fluorescent protein technology. J Cell Sci 120:4247-4260

Shick JM, Lesser MP, Dunlap WC, Stochaj WR, Chalker BE, Won JW (1995) Depth-dependent responses to solar ultraviolet radiation and oxidative stress in the zooxanthellate coral Acropora microphthalma. Mar Biol 122:41-51

Smith DJ, Suggett DJ, Baker NR (2005) Is photoinhibition of zooxanthellae photosynthesis the primary cause of thermal bleaching in corals? Glob Change Biol 11:1-11

Smith-Keune C, Dove S (2008) Gene expression of a green fluorescent protein homolog as a host-specific biomarker of heat stress within a reef-building coral. Mar Biotechnol (NY)10:166-180

> Takabayashi M, Hoegh-Guldberg O (1995) Ecological and physiological differences between two colour morphs of the coral Pocillopora damicornis. Mar Biol 123:705-714

Wiedenmann J (1997) Die Anwendung eines orange fluoreszierenden Proteins und weiterer farbiger Proteine und der zugehörenden Gene aus der Artengruppe Anemonia sp. (sulcata) Pennant, (Cnidaria, Anthozoa, Actinaria) in Gentechnologie und Molekularbiologie. Patent DE 19718640 Deutsches Patent- und Markenamt, München, p 1-18

Wiedenmann J, Nienhaus GU (2006) Live-cell imaging with EosFP and other photoactivatable marker proteins of the GFP family. Expert Rev Proteomics 3:361-374

Wiedenmann J, Röcker C, Funke W (1999) The morphs of Anemonia aff. sulcata (Cnidaria, Anthozoa) in particular consideration of the ectodermal pigments. Verh Ges Ökol 29:497-503

Wiedenmann J, Elke C, Spindler KD, Funke W (2000) Cracks in the beta-can: fluorescent proteins from Anemonia sulcata (Anthozoa, Actinaria). Proc Natl Acad Sci USA 97: 14091-14096

Wiedenmann J, Schenk A, Rocker C, Girod A, Spindler KD, Nienhaus GU (2002) A far-red fluorescent protein with fast maturation and reduced oligomerization tendency from Entacmaea quadricolor (Anthozoa, Actinaria). Proc Natl Acad Sci USA 99:11646-11651

Wiedenmann J, Ivanchenko S, Oswald F, Nienhaus GU (2004) Identification of GFP-like proteins in nonbioluminescent, azooxanthellate Anthozoa opens new perspectives for bioprospecting. Mar Biotechnol 6:270-277

Wiedenmann J, Vallone B, Renzi F, Nienhaus K, Ivanchenko S, Rocker C, Nienhaus GU (2005) Red fluorescent protein eqFP611 and its genetically engineered dimeric variants. J Biomed Opt 10:014003 